\title{
A Huge Renal Cell Carcinoma, Nine Years after Its Primary Diagnosis and Obligate Observation
}

\author{
Mohammad Kazem Moslemi ${ }^{\mathrm{a}}$ \\ Seiied Jalal Esshagh Hosseini ${ }^{b}$ \\ Mohammad Hasan Dehghani Firoozabadic
}

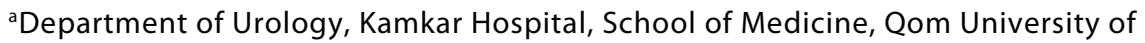
Medical Sciences, b Department of Surgery, Shahid Beheshti Hospital, School of Medicine, Qom University of Medical Sciences, Qom, and 'Department of Urology, Rahnemoon Hospital, School of Medicine, Yazd University of Medical Sciences, Yazd, Iran

\section{Key Words}

Renal cell carcinoma · Radical nephrectomy · Large renal masses · Tumor growth

\begin{abstract}
The clinical diagnosis of renal cell carcinoma $(\mathrm{RCC})$ is radiographic. Effective imaging of the kidneys can be achieved by ultrasound, CT or MRI [Chawla et al.: J Urol 2006;175:425431]. Solid lesions detected by ultrasound and those showing enhancement on crosssectional imaging are considered malignant until proven otherwise. The standard of care for clinically localized RCC remains surgical resection due to the favorable prognosis associated with surgery and the relative ineffectiveness of systemic therapy. Since patients with localized RCC are often symptom-free, they sometimes refuse to receive surgical treatment or are left untreated based on a diagnosis of benign lesions. There are also cases where an RCC is relatively large and causes symptoms but is not treated surgically because of complications and other reasons. We report a 54-year-old male who underwent a difficult radical nephrectomy 9 years after the primary RCC malignancy diagnosis.
\end{abstract}

\section{Case Presentation}

The patient is a 54-year-old male who was referred to our clinic due to a large abdominal mass. He complained of early satiety, anorexia, weakness and weight loss during the 6 months before admission. Nine years ago, he had noticed the presence of a $4-$ to $5-\mathrm{cm}$ right renal mass. His chief complaint at that time was intermittent gross hematuria. He was advised to have surgery but due to financial constraints, he refused the surgery. In the physical examination, a distended abdomen was evident in the supine 
position (fig. 1). A right-sided grade III varicocele was apparent. BMI was 22. In the hematological evaluation, $\mathrm{Hgb}$ was $10.5 \mathrm{~g} / \mathrm{dl}$. Other biochemistry data was normal. In abdominopelvic sonograghy a large solid mass of $25 \times 15 \mathrm{~cm}$ was reported. A huge hypervascularized mass was evident on MRI, which occupied all of the right side of the abdomen without any evidence of direct invasion of the inferior vena cava (fig. 2). Chest X-ray was negative for metastasis. A whole body bone scan was negative for skeletal metastasis. He underwent right radical nephrectomy by laparotomy incision (fig. 3). After a very difficult procedure with severe bleeding, the tumor (fig. 4), weighing 2,500 g and measuring $25 \times 20 \times$ $12 \mathrm{~cm}$, was excised. Its histopathology diagnosis was consistent with clear cell RCC with grade 2 Fuhrman nuclear grading. The patient is still well one year after operation as revealed by CT scan (fig. 5).

\section{Discussion}

Due to the increased use of diagnostic imaging for evaluating patients with abdominal symptomatology, the incidence of RCC has increased dramatically during the last three decades and the size of the lesions detected is constantly decreasing $[2,3]$. Incidental detection of asymptomatic tumors now accounts for $48-66 \%$ of all such lesions [4]. Median patient age at RCC diagnosis is now 66 years with the greatest increase in patients 70-90 years old [5]. The percentage of patients presenting with metastatic disease at initial diagnosis remains at 25-35\% [6]. Prompt surgical excision remains the standard of care for localized enhancing renal tumors because of the limited efficacy of systemic therapies for advanced disease $[7,8]$. However, recent data demonstrate that despite earlier diagnosis and treatment there has been no significant decrease in cancer-specific or overall mortality, suggesting an over-treatment bias [3]. Renal masses diagnosed in older and comorbid patients represent a challenge with regard to treatment. In the published literature, only limited experience with 'watchful waiting' or 'active surveillance' with regard to renal masses is available. Currently, the natural history of untreated localized renal tumors is being defined through active surveillance series. A recent meta-analysis of active surveillance series revealed that the majority of renal tumors demonstrated slow interval growth with an average growth rate of $0.28 \mathrm{~cm} /$ year [1]. Moreover, a subset of approximately $30 \%$ of renal tumors did not demonstrate any difference in pathology between growing and nongrowing tumors, and no predictive clinical or radiographic characteristics could be identified in these tumors [9]. Potential predictors of future tumor growth include gender, patient age on presentation and radiographic tumor characteristics. A recent report by Kouba et al. [10] noted a significant correlation between patient age on presentation and linear tumor growth rates. Their data suggests that tumors detected in younger patients exhibit increased linear growth compared to older patients. Potential radiographic predictors of renal lesion growth investigated included lesion size on presentation, presence of cystic components, and the presence of multifocal disease on presentation. In our opinion, the most important question related to observational strategies in RCC management is how the clinical outcome for the patients is affected. As the most definite measure of outcome, we have focused on survival. The $100 \%$ rate of 5 -year cancer-specific survival for patients with tumors $\leq 4 \mathrm{~cm}$ in size is similar in all of the studies. Chawla et al. [11], in their metaanalysis of worldwide literature, reported a progression rate of only $1 \%$ in 286 tumors between 1.73 and $4.08 \mathrm{~cm}$ in size. The length of the follow-up period is essential, as demonstrated by Abou et al. [12] in their long-term follow-up paper. They found progression to metastatic disease in 2 of 35 patients (5.7\%) after 29 and 40 months, respectively, in a group of tumors $\leq 4 \mathrm{~cm}$ in diameter. This underlines the progressive nature of RCC. In large tumors, size is related to a poorer prognosis, and nearly $40 \%$ of 


\begin{tabular}{|c|c|c|c|}
\hline $\begin{array}{l}\text { Case Reports in } \\
\text { Oncolocy }\end{array}$ & \begin{tabular}{|l} 
Case Rep Oncol 2010;3:326-333 \\
DOI: 10.1159/000320941
\end{tabular} & $\begin{array}{l}\text { Published online: } \\
\text { September } 11,2010\end{array}$ & $\begin{array}{l}\text { @ } 2010 \text { S. Karger AG, Basel } \\
\text { ISSN 1662-6575 } \\
\text { www.karger.com/cro }\end{array}$ \\
\hline
\end{tabular}

the patients have metastatic disease at higher stages. A median diameter of $7.5 \mathrm{~cm}$ is related to a $40 \%$ rise of synchronous metastatic disease. It is estimated that the odds of synchronous metastatic disease is increased by $22-38 \%$ by each $1-\mathrm{cm}$ increase in tumor size [13]. The perioperative mortality of some of the patients is important and should be discussed. The rate is difficult to determine. However, Nuttall et al. [14] report an inhospital mortality rate of 3.2 and $4.7 \%$ among patients between $70-79$ and $>80$ years of age, respectively. Most renal masses seem to grow slowly. Most authors report the mean tumor growth rate to be between 0.06 and $0.21 \mathrm{~cm} /$ year for tumors $\leq 4 \mathrm{~cm}$ in size [4]. For larger tumors, a mean tumor growth rate of $0.39 \mathrm{~cm} /$ year is reported [15]. However, delayed intervention of $\geq 1$ year after diagnosis does not seem to worsen the prognosis for later metastatic disease [16]. There is wide variability of observed renal lesions with regard to growth kinetics [17]. Kato et al. [18] described rapidly growing tumors that increased in diameter at 20 times the rate of slowly growing lesions. While it was suggested that tumors that are destined to grow and possibly metastasize do so early and most small tumors grow slowly or not at all [17], to our knowledge no correlation between size at presentation and the growth rate has been firmly established. In the Kunkle DA et al. series [19], only 1 patient showed metastatic disease during observation. In this 84 -yearold patient, a $2-\mathrm{cm}$ mass grew to $8 \mathrm{~cm}$ during 54 months of follow-up. With only 3 such cases reported in the literature, it is difficult to accurately establish the rate at which sporadic, clinically localized RCC progress to metastatic disease while under surveillance. The patients with symptoms trended toward a more rapid growth rate than asymptomatic patients. However, progression of symptoms may warrant definitive therapy and should be carefully considered in patient discussions. Age was perhaps the strongest predictor of tumor growth, with younger patients having more rapid growth rates than older patients [7]. Fujimoto et al. [20] analyzed the doubling time in 18 cases of renal carcinoma and reported a doubling time of $466 \pm 84.6$ days for primary lesions and $89.4 \pm 43$ days for metastatic lesions in the lungs. The risk of developing metastatic disease is the primary indication for initiating active surveillance of enhancing renal tumors. Younger patients may be more susceptible to rapid growth and should be treated accordingly.

\section{Conclusion}

The majority of enhancing renal tumors undergoing active surveillance demonstrates slow interval growth. Tumor growth kinetics may provide a way of identifying aggressive behavior of renal tumors. For this reason, immediate surgical excision is indicated for patients with enhancing renal tumors who are acceptable surgical candidates. The risk of disease progression is significantly higher in patients with larger renal masses $(>4 \mathrm{~cm})$. The data from this case report and those of others support that even the rapidly growing or large renal tumors may be managed expectantly, but with increased vigilance [15]. Delayed intervention does not appear to adversely impact pathological outcomes. This case is the first report about the obligate observation of a large renal tumor for the long period of 9 years without finding any evidence of metastasis. 


\begin{tabular}{c|l|l|l}
$\begin{array}{c}\text { Case Reports in } \\
\text { Oncology }\end{array}$ & $\begin{array}{l}\text { Case Rep Oncol 2010;3:326-333 } \\
\text { DOI: 10.1159/000320941 }\end{array}$ & $\begin{array}{l}\text { Published online: } \\
\text { September 11, 2010 }\end{array}$ & $\begin{array}{l}\text { O 2010 S. Karger AG, Basel } \\
\text { ISSN 1662-6575 } \\
\text { www.karger.com/cro }\end{array}$ \\
\hline
\end{tabular}

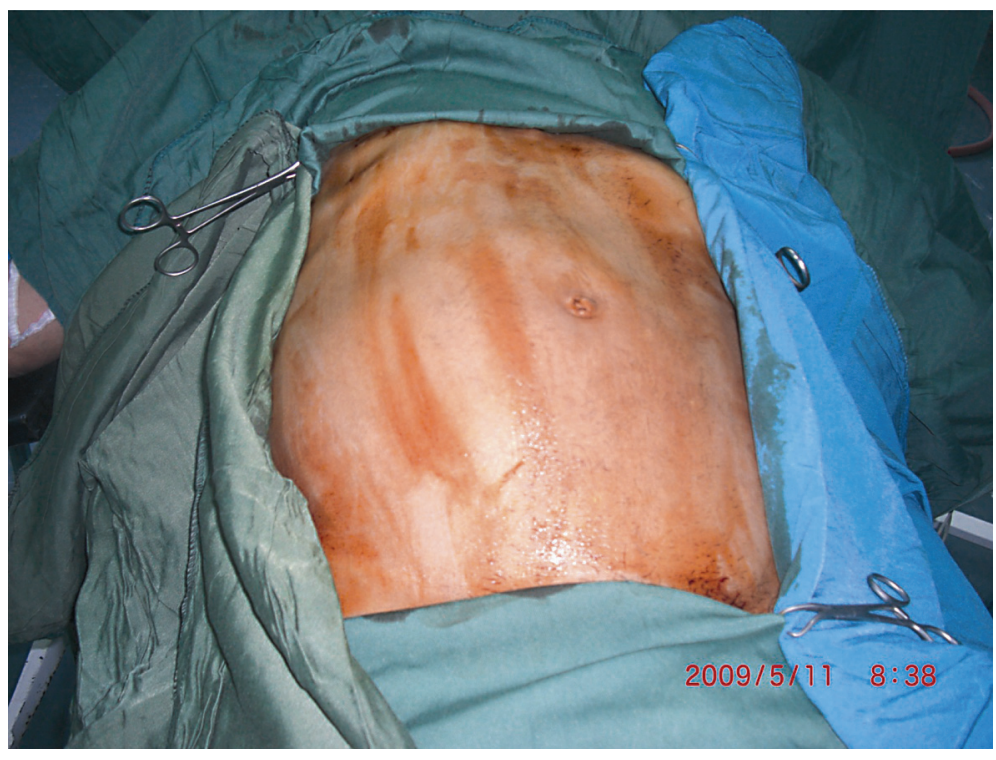

Fig. 1. The formal appearance of the abdomen before operation. Tumoral distention of the abdomen is evident. 


\begin{tabular}{r|l|l|l}
$\begin{array}{c}\text { Case Reports in } \\
\text { Oncology }\end{array}$ & $\begin{array}{l}\text { Case Rep Oncol 2010;3:326-333 } \\
\text { DOI: 10.1159/000320941 }\end{array}$ & $\begin{array}{l}\text { Published online: } \\
\text { September 11, 2010 }\end{array}$ & $\begin{array}{l}\text { O 2010 S. Karger AG, Basel } \\
\text { ISSN 1662-6575 } \\
\text { www.karger.com/cro }\end{array}$ \\
\hline
\end{tabular}
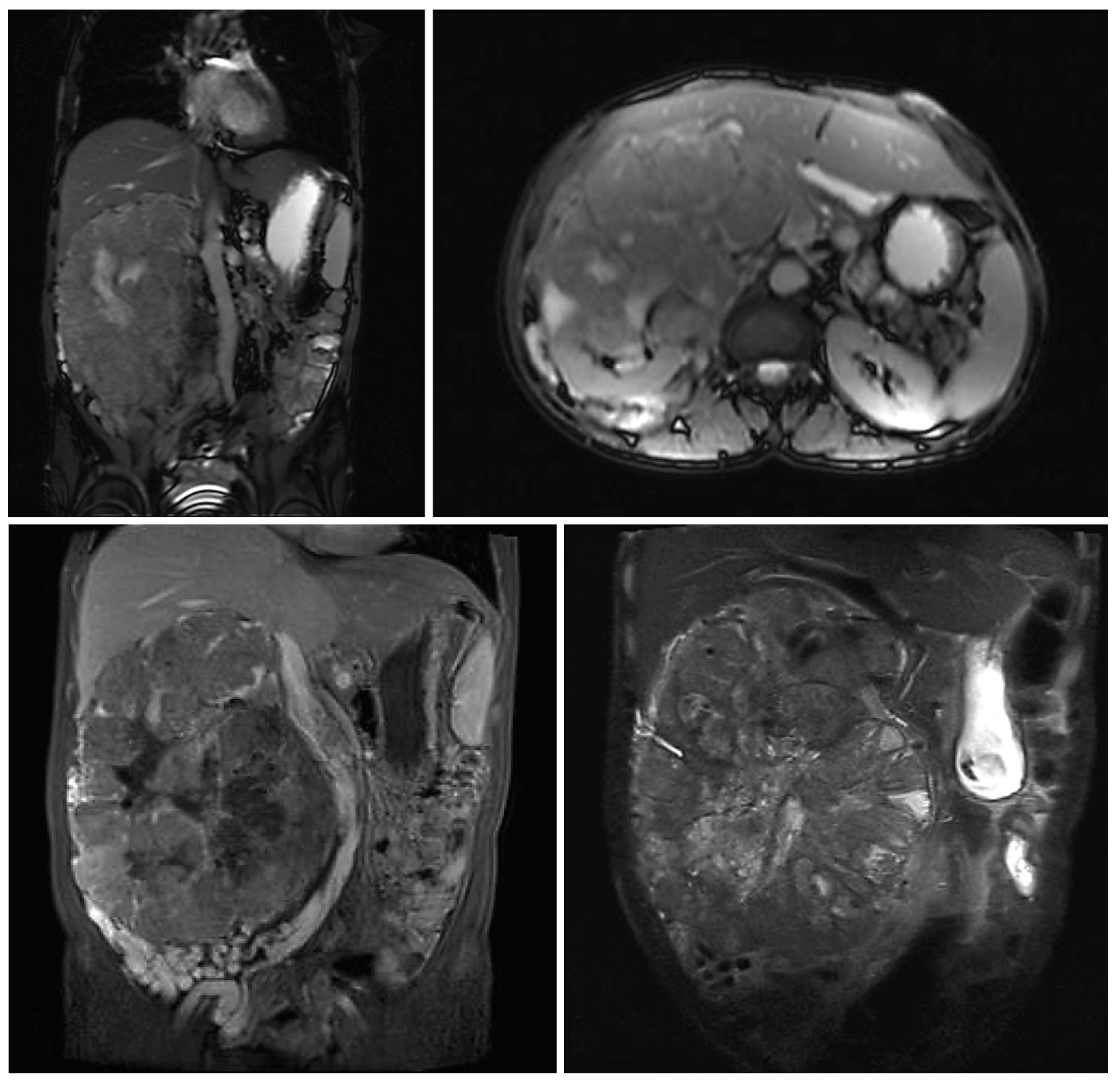

Fig. 2. MRI of the abdomen, multiple views. The large tumor occupied half of the abdomen. 


\begin{tabular}{c|l|l|l}
$\begin{array}{c}\text { Case Reports in } \\
\text { Oncology }\end{array}$ & $\begin{array}{l}\text { Case Rep Oncol 2010;3:326-333 } \\
\text { DOI: 10.1159/000320941 }\end{array}$ & $\begin{array}{l}\text { Published online: } \\
\text { September 11, 2010 }\end{array}$ & $\begin{array}{l}\text { 2 2010 S. Karger AG, Basel } \\
\text { ISN 1662-6575 } \\
\text { www.karger.com/cro }\end{array}$ \\
\hline
\end{tabular}

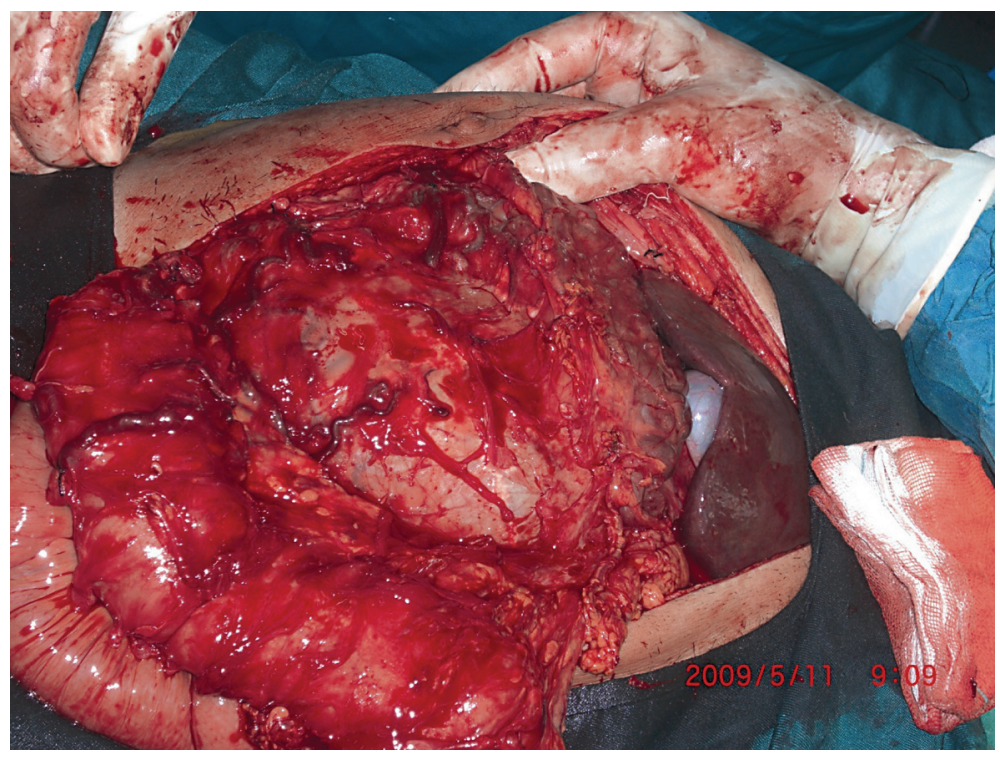

Fig. 3. The appearance of the tumor after peritoneal opening.

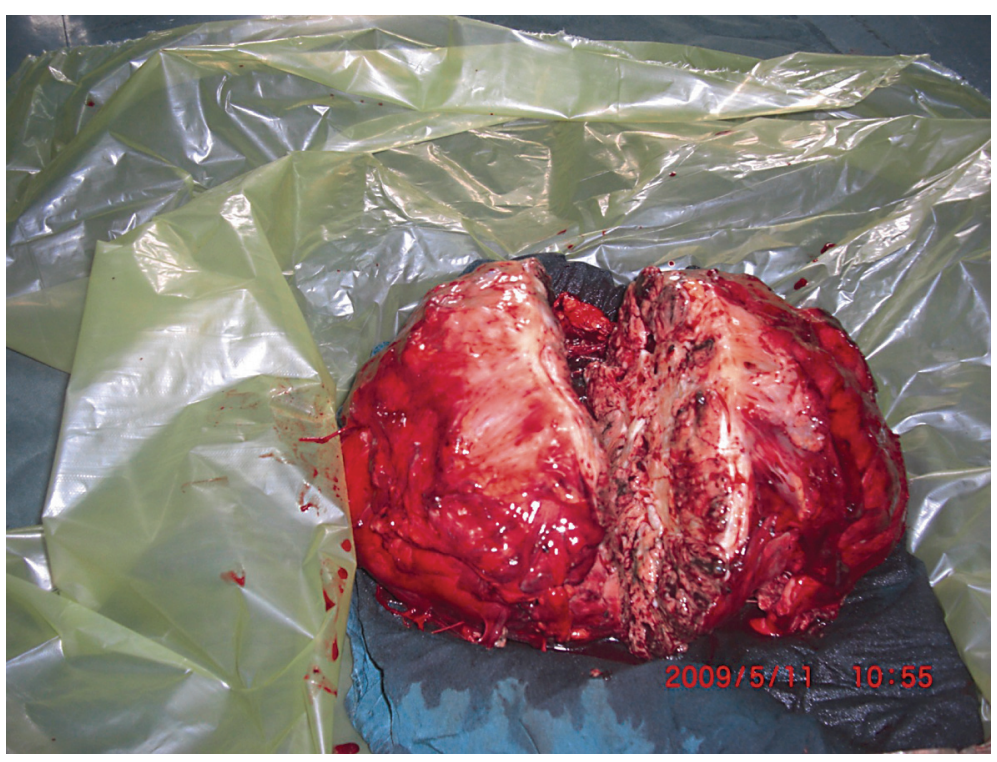

Fig. 4. The hypervascularized tumor after excision. 


\begin{tabular}{c|l|l|l}
$\begin{array}{c}\text { Case Reports in } \\
\text { Oncology }\end{array}$ & $\begin{array}{l}\text { Case Rep Oncol 2010;3:326-333 } \\
\text { DOI: 10.1159/000320941 }\end{array}$ & $\begin{array}{l}\text { Published online: } \\
\text { September 11, 2010 }\end{array}$ & $\begin{array}{l}\text { O 2010 S. Karger AG, Basel } \\
\text { ISSN 1662-6575 } \\
\text { www.karger.com/cro }\end{array}$ \\
\hline
\end{tabular}

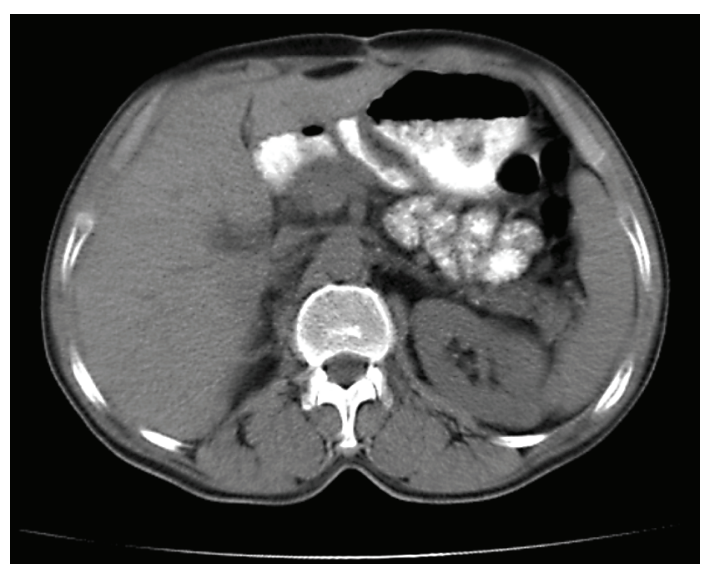

Fig. 5. Postoperative CT scan, one year after operation, revealing unremarkable, tumor-free state.

\section{References}

1 Chawla SN, Crispen PL, Hanlon AL, Grennberg RE, Uzzo RG: The natural history of observed enhancing renal masses: meta-analysis and review of the world literature. J Urol 2006;175:425-431.

$\checkmark 2$ Chow WH, Devesa SS, Warren JL, Fraumeni JF Jr: Rising incidence of renal cell cancer in the United States. JAMA 1999;281:1628-1631.

-3 Hollingsworth JM, Miller DC, Daignault S, Hollenbeck BK: Rising incidence of small renal masses: a need to reassess treatment effect. J Natl Cancer Inst 2006;98:1331-1334.

4 Volpe A, Panzarella T, Rendon RA, Haider MA, Kondylis FI, Jewett MA: The natural history of incidentally detected small renal masses. Cancer 2004;100:738-745.

-5 Frank I, Blute ML, Leibovich BC, Cheville JC, Lohse CM and Zincke H: Independent validation of the 2002 American Joint Committee on cancer primary tumor classification for renal cell carcinoma using a large, single institution cohort. J Urol 2005;173:1889.

6 Hock LM, Lynch J, Balaji KC: Increasing incidence of all stages of kidney cancer in the last decades in the United States: an analysis of surveillance, epidemiology and end results program data. J Urol 2002;167:57-60.

7 Clark JI, Atkins MB, Urba WJ, et al: Adjuvant high dose bolus interleukin-2 for patients with high-risk renal cell carcinoma: a cytokine working group randomized trial. J Clin Oncol 2003;21:3133-3140.

-8 Negrier S, Escudier B, Lasset C, et al: Recombinant human interleukin-2, recombinant interferon alfa-2a, or both in metastatic renal-cell carcinoma. Group Français d'Immunothérapie. N Engl J Med 1998;338:12721278.

-9 Kunkle DA, Crispen PL, Chen DY, Greenberg RE, Uzzo RG: Enhancing renal masses with zero net growth during active surveillance. J Urol 2007;177:849-854.

10 Kouba E, Smith A, McRackan D, Wallen EM, Pruthi RS: Watchful waiting for solid renal masses: insight into the natural history and results of delayed intervention. J Urol 2007;177:466-470.

-11 Chawla SN, Crispen PL, Hanlon AL, Greenberg RE, Chen DY, Uzzo RG: The natural history of observed enhancing renal masses: meta-analysis and review of the world literature. J Urol 2006;175:425-431.

12 Abou YT, Kassouf W, Steinberg J, Aprikian AG, Laplante MP, Tanguay S: Active surveillance for selected patients with renal masses. Updated results with long-term follow-up. Cancer 2007;110:1010-1014.

13 Klatte T, Patard JJ, de Martino M, et al: tumor size does not predict risk of metastatic disease or prognosis of small renal cell carcinoma. J Urol 2008;179:1719-1726.

14 Nuttall M, Cathcart P, van der Meulen J, Gillatt D, McIntosh G, Emberton M: A description of radical nephrectomy practice and outcomes in England: 1995-2002. BJU Int 2005;96:58-61.

15 Lamb GW, Bromwich EJ, Vasey P, Aitchison M: Management of renal masses in patients medically unsuitable for nephrectomy - natural history, complications, and outcome. Urology 2004;64:909-913.

16 Crispen PL, Viterbo R, Fox EB, Greenberg RE, Chen DY, Uzzo RG: Delayed intervention of sporadic renal masses undergoing active surveillance. Cancer 2008;112:1051-1057. 
17 Rendon RA, Stanietzky N, Panzarella T, Robinette M, Klotz LH, Thurston W, et al: The natural history of small renal masses. J Urol 2000;164:1143.

18 Kato M, Suzuki T, Terasawa Y, Sasano H and Arai Y: Natural history of small renal cell carcinoma: evaluation of growth rate, histological grade, cell proliferation and apoptosis. J Urol 2004;172:863.

19 Kunkle DA, Crispen PL, Chen DY, Greenberg RE, Uzzo RG: Enhancing renal masses with zero net growth during active surveillance. J Urol 2007;177:849-853.

20 Fujimoto N, Sugita N, Terasawa Y, Kato M: Observations on the growth rate of renal cell carcinoma. Int J Urol 1995;2:71-76. 